\title{
Beyond the Shadow of White Privilege?: The Socioeconomic Attainments of Second Generation South Asian Americans
}

\author{
Hyeyoung $\mathrm{Woo}^{1 *}$, Arthur Sakamoto ${ }^{2}$, Isao Takei ${ }^{3}$ \\ ${ }^{1}$ Department of Sociology, Portland State University, Portland, USA \\ ${ }^{2}$ Department of Sociology, University of Texas, Austin, USA \\ ${ }^{3}$ Department of International Relations, Nihon University, Mishima-City, Japan \\ Email: "hyeyoung@pdx.edu
}

Received June $7^{\text {th }}$, 2011; revised September $4^{\text {th }}$, 2011; accepted November $15^{\text {th }}$, 2011

\begin{abstract}
Despite numerous studies of second generation minorities in recent years, South Asian Americans have been largely ignored. Using the most recent data available from the US Census Bureau, we investigate the socioeconomic attainments of second generation South Asian Americans. We find that their average levels of education, wages, and occupational attainment exceed those of non-Hispanic whites. Contrary to the "model minority myth" view, second generation South Asian Americans remain slightly advantaged relative to non-Hispanic whites in terms of labor market success net of age, education, and region of residence. These results are also inconsistent with discussions of white privilege that emphasize the socioeconomic disadvantages of minorities with darker skin tones. Our results suggest that theories of race relations should also incorporate South Asian Americans.
\end{abstract}

Keywords: South Asian Americans; White Privilege; Second Generation; Wages

\section{Introduction}

\section{South Asian Americans and White Privilege}

Prior research has not investigated the socioeconomic attainments of second generation South Asian Americans. Because South Asian Americans are currently classified into the Asian American category as defined by the US Census Bureau, they have been included in the samples used to study Asian Americans overall (Sakamoto \& Furuichi, 2002). However, South Asian Americans have rarely been considered separately using multivariate statistical analysis with nationally representative data. Given their increasing population size and high growth rate (Min, 2006), this omission from the literature needs to be addressed. We still do not have adequate information about how the socioeconomic attainments of South Asian Americans may differ from those for non-Hispanic whites and Asian Americans overall (see Sakamoto, Goyette, and Kim (2009) for a recent review of the latter).

In addition to being a significant demographic group worthy of investigation, South Asian Americans have a broader theoretical significance in terms of the debate on white privilege. Although the literature on the latter is complex and highly theoretical, a common assumption in many of these writings is that racial and ethnic minorities with darker skin tones are disadvantaged in American society (Bonilla-Silva, 2001; Feagin, 2001; Omi \& Winant, 1994). As discussed by Saenz and Morales (2005), the "whiteness" literature emphasizes the extent to which whites gain socioeconomic advantages because of "structural arrangements" that provide them greater opportunities in terms of college admissions, job interviews, improved labor market rewards, and greater acceptance by whites in desirable residential neighborhoods and schools. By contrast,

*Corresponding author. darker-skinned minorities are incorporated into subordinate positions in the "racialized stratification system" due to their “collective blackness” (Saenz \& Morales, 2005: p. 173). Whites will be always at the top of the social structure, and "a hierarchical racial order continues to shape all aspects of American life” (Bonilla-Silva \& Glover, 2004: p. 28).

According to Bonilla-Silva (1997), prejudice against persons with darker skin tones has been so thoroughly ingrained into American culture for so long that these negative attitudes cannot be easily dismantled. Bonilla-Silva (1997: p. 475) argues that American institutions have evolved with centuries of racist relations so that racism must still be a significant feature of American labor markets because "racialization develops a life of its own”. As stated by Feagin and Vera (1995: p. 7), "White racism can be viewed as the socially organized set of attitudes, ideas, and practices that deny African Americans and other people of color the dignity, opportunities, freedoms, and rewards that this nation offers white Americans". Because whites will probably become a numerical minority in the US by 2070, whites need to preserve and consolidate their racial power by continuing to denigrate darker-skinned persons and to maintain the socioeconomic privileges of light-skinned persons (BonillaSilva, 2003).

Our objective here is not, however, to summarize or review the literature on white privilege, but to investigate the socioeconomic attainments of second generation South Asian Americans which relate to one the most basic assumptions of that literature. In doing so, we assume that South Asian Americans have, at least on average, darker skin tones than white Americans of European ancestry (i.e., non-Hispanic whites). For this reason, the white privilege literature suggests the hypothesis that South Asian Americans should face a net racial disadvantage in their socioeconomic attainments. Assuming that they tend to have darker skin tones (on average), South Asian Ameri- 
cans are predicted to face fewer opportunities in the labor market and are consequently hypothesized to have lower wages and occupational attainment (on average) relative to non-His- panic whites (i.e., persons with lighter skin tones) after controlling for relevant educational attainment and other demographic factors relating to labor market outcomes.

In drawing out this hypothesis, we hasten to add and fully recognize that skin tones vary considerably within the South Asian and South Asian American communities. This fact is reflected in the early history of South Asian Americans when debates considered whether South Asians should be classified as whites (Takaki, 1998: pp. 294-301; Kitano \& Daniels, 2000: p. 107) due to the fair complexions of at least some persons from South Asia. Most of the early South Asian immigrants were from northern India (i.e., Punjab) and they are sometimes described as having light skin tones (Takaki, 1998). Although the Thind decision handed down by the US Supreme Court in 1923 ruled against the legal treatment of South Asians as being classified as white, the fact that many states had earlier ruled in favor of categorizing South Asians as whites (Jensen, 1988) is suggestive of light skin tones among at least some of the South Asian immigrants especially at that time.

In our study, we do not have data on the skin tones of the respondent nor are we aware of any socioeconomic data for the US that includes such information. We therefore do not directly test the white privilege hypothesis using data on skin color. We can, however, indirectly investigate the hypothesis by making the assumption that South Asian Americans have darker skin tones than non-Hispanic whites albeit only in terms of an average (i.e., not in all individual cases). Nonetheless, because our statistical analyses investigate average tendencies in the data (i.e., using regression analysis which is in essence a multivariate model of conditional averages), this on-average reasoning is appropriate given our research methods.

Consistent with our major assumption, Stokowski et al. (2007) identify a genetic basis for skin tone in the South Asian population. Their results show that genetic polymorphisms relating to three specific genes (i.e., SLC24A5, TYR, and SLC45A2) explain a very large fraction of the melanin content of skin across the South Asian individuals in their study. This research was based on a volunteer sample of over 50 adults who identified themselves as being of "South Asian descent". The results furthermore show that, based on the birthplaces of a respondent's four grandparents in terms of the specific South Asian locale organized into regional areas (i.e., Punjab, Gujarat, Ski Lanka, Bangladesh, etc.), variation in the level of melanin content can be substantially explained. Stokowski et al. (2007: pp. 1129-1130) also discuss how related research on samples of the white population (who identify themselves as having a European ancestry) tend to have notably different genetic patterns that are associated with lower melanin content as compared to their South Asian sample. Thus, the results of Stokowski et al. (2007) are consistent with our underlying assumption that South Asian Americans tend to have darker skin tones than non-Hispanic whites at least on average.

Recent qualitative research by Dingra (2003) furthermore finds that second generation South Asian Americans continue to be generally viewed as being a non-white racial minority. Even when they may be highly educated and employed in a relatively high status occupation, second generation South Asian Americans are generally seen by whites as having a separate ethnic identity that needs to be curtailed and highly controlled in a professional setting. When combined with the findings of Stokowski et al. (2007) regarding the tendency for darker skin tones on average, the results of Dingra (2003) underscore the need to investigate the possibility of continuing racial discrimination against second generation South Asian Americans because they appear to be readily viewed by whites as being a non-white racial minority.

\section{Studying the Socioeconomic Attainments of Second Generation Asian Americans}

The sociological literature on the socioeconomic attainments of Asian Americans has often emphasized the view that this racial category faces discrimination in the labor market (Sakamoto, Goyette, \& Kim, 2009). Perhaps the most famous reference on this topic is Hirschman and Wong (1984) who argued for the "model minority myth" (MMM) view which states that "Asian Americans approach socioeconomic parity with whites because of their overachievement in educational attainment" (Hirschman \& Wong, 1984: p. 584). That is, Hirschman and Wong (1984) contend that the average earnings and occupational attainments of Asian Americans do not differ very much from those of whites. However, because Asian Americans tend to have higher educational attainments than do whites, the labor market is said to be actually discriminating against Asian Americans in as much as they must make a higher investment in human capital in order to obtain the same overall socioeconomic rewards as do whites. As stated by Hirschman and Wong (1984: p. 602), “The apparent equality between Asians and whites is largely a function of educational overachievement by Asians. If Asians experienced the same process of stratification as whites, their educational credentials would shift their (Asians) occupational and earnings levels substantially above those of the majority population”.

A succinct summary of the MMM perspective is provided by (Hurh \& Kim, 1989: p. 512) who concluded that "our analyses in the light of the principle of earnings equity indicate that the success image (of Asian Americans) is largely a myth due to labor market disadvantages and other related social problems". Similar conclusions are reached by Zhou and Kamo (1994), Waters and Eschbach (1995), McCall (2001), Zhou (2004), and Snipp and Hirschman (2005). According to Hirschman and Snipp (2001: p. 634):

...the sources of the Chinese and Filipino disadvantage are current residence, labor market positions, and unmeasured factors. Their potential disadvantage is reduced by their higher levels of schooling. In fact, their educational advantage over whites generates (all else equal) about a \$5000 gain. Without this educational "boost", their economic situations would be similar to the level of blacks, American Indians, and Hispanics... These results - the persistence of race and ethnic differentials in late twentieth-century America-challenge conventional theories about the declining role of ascribed factors in the American stratification system...

Though not extensively connected in prior research, the MMM view (as evident in the above study by Hirschman and Snipp among others) seems to be broadly consistent with the white privilege literature discussed above. Both approaches represent a fundamental critique of American society in that they both point to continuing racism as embedded in existing institutional structures including those pertaining to labor market outcomes.

In order to investigate these perspectives systematically with 
empirical data, we study the most recent data from the US Census Bureau. Due to the lack of a prior quantitative research on South Asian Americans to build upon, we emphasize that our investigation represents only a small first step towards a broader literature that hopefully will eventually develop. While a full blown statistical analysis of the entire South Asian American community is ultimately desirable, space and data constraints prevent us from engaging in a more extensive analysis in this paper.

First, we limit our study to the second generation. Kibria's (2006) descriptive statistics indicate some significant socioeconomic differences between foreign-born and native-born South Asian Americans. In addition, previous research on Asian Americans finds that native-born Asian Americans systematically differ from their foreign-born immigrant counterparts in terms of labor market processes (Zeng \& Xie, 2004). In keeping with prior research, we follow the practice of including in our analysis persons who are foreign born but who came to the US at a young age (i.e., 12 years old or younger) and are therefore schooled and socialized primarily in the US (Portes \& Rumbaut, 2005; Portes \& Zhou, 1995). When there is a need to be specific, we refer to this latter group as the " 1.5 generation". Following the usual custom in this field, however, we use the term "second generation" to include both the 1.5 generation as well as the native-born offspring of foreign-born immigrants (Farley \& Alba, 2002).

From a more substantive point of view, our specific research objective is to estimate the net racial disadvantage for South Asian Americans rather than assessing the various disadvantages of being an immigrant. Immigrants are less familiar with American labor market practices that may be further obfuscated by cultural differences and reduced social networks (e.g., Duleep \& Regets, 1997; Min, 1995). The quality of training obtained in foreign universities is often of lower quality than that obtained in US universities (Bratsberg \& Ragan, 2002). As noted by Sanders and Nee (1996: p. 232), "US employers are ill-prepared to evaluate foreign-earned human capital” which exacerbates skill transfer problems among immigrants. Although South Asian immigrants are much more likely than most other Asian immigrants to speak English well, a significant proportion of South Asian immigrants nonetheless do not (Reeves \& Bennett, 2004: p. 11) and may therefore encounter some language problems when entering the US labor market. Finally, foreign-born immigrants of all racial backgrounds may be disadvantaged in the labor market due to limitations associated with visa and non-citizenship restrictions.

By contrast, these sorts of labor market issues are virtually absent or are at least trivial for most of the second generation. The second generation is socialized and schooled primarily in the US and is therefore more likely to be comparable to nonHispanic whites in terms of unmeasured aspects of labor market qualifications such as fluency in English. For this reason, focusing on the second generation yields estimates of net wage differentials that may be more confidently interpreted as representing a racial disadvantage per se rather than deriving from some aspect of immigration that is not adequately controlled for in the statistical model. That is, the estimated wage disadvantages would be more arguably associated with the persistence of racial discrimination that is our main theoretical concern stemming from the MMM view and discussions of white privilege.

Although Kibria (2006) provides some descriptive statistics for South Asian Americans using recent data, her results do not address the hypothesis that South Asian Americans face a systematic racial disadvantage net of their investments in education and other labor force characteristics as claimed by the MMM approach. One earlier study, however, used the 1980 US Census data for native-born Asian Americans and reported that the wages of South Asian American men were about 20\% lower (as compared to non-Hispanic whites) net of education and other demographic factors (Duleep \& Sanders, 1992: p. 421). That result supports the MMM view for second generation South Asian American men, but the study did not find similar evidence for East Asian American (i.e., Chinese, Filipino, Japanese and Korean) men (Duleep \& Sanders, 1992: p. 421). These findings suggest the possibility that second generation South Asian American men may be somewhat different from East Asian American in terms of labor market outcomes. If so, then the darker skin tones among South Asian American men might perhaps be considered as a potential factor.

On the basis of that prior study by Duleep and Sanders (1992), we argue that the white privilege hypothesis- that minorities with darker skin tones are significantly disadvantaged in the US labor market relative to non-Hispanic whites-needs to be seriously investigated for second generation South Asian Americans. In the following, we seek to test this hypothesis using a large sample size for more recent data as well as extending the analysis to South Asian American women who have not been previously considered in prior literature. Multivariate analysis is needed for the study of South Asian Americans because without it, systematic evidence on racial disparities in the labor market cannot be rigorously assessed using nationally representative data.

\section{Data and Methods}

We use the 2006, 2007 and 2008 American Community Survey (ACS) which are the most up-to-date data available with an adequate sample size to study racial minorities. The ACS is also one of the very few data sets that identifies South Asian Americans rather than lumping them into the overall Asian American category. In the following, we define the South Asian American category as including persons who identified themselves as Asian Indian, Bangladeshi, Pakistani or Sri Lankan. The large majority of our sample is, however, Asian Indian due to the much larger demographic size of that South Asian group in the US. ${ }^{1}$

Our study of socioeconomic attainments is focused on persons aged 25 to 64 who had some employment in the labor force during the year prior to the survey. The OLS regression models of the hourly wage rate use the logarithmic transformation as the dependent variable which is standard in labor force studies due to the positive skew in the distribution of wages (Sakamoto \& Furuichi, 1997). Additional regression models are estimated which use as the dependent variable 4 broad occupational categories that are assumed to be hierarchically rewarded (at least on average) in terms of the rewards typically associated with the jobs in a given occupational category (e.g., earnings,

${ }^{1}$ Unfortunately, the sample sizes for Bangladeshi, Pakistani, and Sri Lankan Americans were too small to treat them as separate categories in our statistical analysis. We do not consider other South Asian groups (e.g., Burmese, Maldivians, Nepalese) because they are more difficult to identify with the ACS and because they are unlikely to be present in significant numbers in these sample data especially in regard to our target population which is the adult second-generation. 
social status, desirable work conditions, etc.). Based on the occupational codes that are available in the ACS, these 4 hierarchical categories include: 1) management, business, finance, computer, engineering, science, education, legal, community service, arts, media, healthcare and technical occupations; 2) service, sales, office and administrative support occupations; 3) construction, extraction, installation, maintenance, repair, production, transportation and material moving occupations; and 4) farming, fishing and forestry occupations. Due to the ordinal nature of these occupational categories when used as a dependent variable, the appropriate statistical model is ordered logistic regression. In keeping with the recommendation of ACS technical documentation, all of our computed statistics apply sampling survey weights.

As noted above, we limit the analysis to the second generation. Although our data do not specifically include a variable to identify generational status, we refer to native-born South Asian Americans who are over 25 years of age as being second generation because the vast majority of the South Asian population are post-1965 immigrants (Min, 2006). ${ }^{2}$ As an additional control variable, however, these data do permit us to identify the 1.5 generation which we define as persons who were born in another country but who came to the US at age 12 or younger. Our statistical analysis is broken down by gender because our main substantive focus is on identifying racial differentials per se.

The independent variables for both the log-wage regression and the ordered logistic regression include years of age, a quadratic term for years of age, a dichotomous variable to indicate whether 1.5 generation, a dichotomous variable to indicate whether South Asian, a set of dichotomous variables to indicate the highest level of schooling completed, and a set of dichotomous variables to indicate region of residence in terms of the major US Census Bureau divisions. Because Sakamoto, Goyette, and Kim (2009) discuss how regional mobility is higher among Asian Americans due to their higher educational levels which lead them to be more involved in particular labor markets that are more likely to be national in scope (e.g., college professors), we estimate two versions of the regression models. The first does not include the controls for region of residence while the second does. This approach follows the recommendation of Sakamoto, Goyette, and Kim (2009) who question whether current region of residence can be treated as an exogenous independent variable in regard to labor market outcomes for more highly educated workers.

Related to this issue, we note that we seek to avoid the problem of what Sakamoto and Furuichi (1997: p. 183) refer to as "over-controlling” in regression models. Including measures such as occupational category or industrial sector as independent variables in the regression equations results in a model in which the racial effects are net of the type of job (in terms of occupation or industry). These results therefore indicate racial inequality within jobs and do not assess racial inequality that derives from racial differences in being assigned to different jobs in the first place (i.e., racial inequality in job attainment). Given the research objective of estimating the total level of racial inequality that is generated by the labor market (i.e., both within and between jobs), the earnings regression should only include the human capital investments, credentials, productive abilities and other endowments that the workers bring to the

${ }^{2}$ We also exclude persons who report multi-racial ancestry although they are very small in number in the case of adult South Asian Americans. labor market very early in their work careers so that these characteristics are not themselves a reflection of discrimination in the labor market.

\section{Empirical Results}

\section{Statistical Findings for Men}

Table 1 shows the descriptive statistics for non-Hispanic white (hereafter "white”) and South Asian American (hereafter "South Asian”) men.

They are broken down for the age range from 25 to 64 and from 25 to 40 . The results for the larger age range from 25 to 64 show that the mean age for white men is 43.4 while the mean age for South Asian men is 32.5. This is a large difference of over ten years that undoubtedly reflects the fact that most second generation South Asians are part of the post1965 immigration stream as described earlier. Table $\mathbf{1}$ also shows that the standard deviation (i.e., variability) in age is much larger for white than for South Asian men which complicates the issue of providing adequate statistical controls in multivariate analysis. Due to these results as well as our chief research concern of estimating the net racial effect per se, our focus in the following will be on the more comparable age range of 25 to 40 among whom the mean age for white men is 32.6 while the mean age for South Asian men is 31.4 as shown in Table 1.

Other results in Table 1 indicate that, among men aged 25 to 40, South Asians are much more likely than whites to have a college or graduate degree; to reside in the Middle Atlantic or Pacific regions; to be employed in the highest occupational category; and to be 1.5 generation. Table $\mathbf{1}$ also shows that South Asian men have higher average wages whether measured in terms of actual dollars or log-dollars. The sample size for South Asian men in the 25 to 40 age range is 2240 which is generally adequate for multivariate analysis.

Table 3 shows the estimates for the ordered logistic regression of occupational attainment for men in the 25 to 40 age range. The estimates are generally consistent with prior research in that occupational attainment is notably increased by higher educational attainment. Other positive effects in Table 3 include age and 1.5 generation. These estimated coefficients are fairly similar in both Models 1 and 2 indicating that they are not much affected by controlling for region.

Contrary to the expectations of the MMM view and white privilege theory, however, the net racial effect for South Asian men is actually positive as well as statistically significant at any conventional level. This statistical advantage in occupational attainment is evident in both Models 1 and 2 in Table 3. After controlling for region in Model 2, South Asian men have a net advantage over white men of $77 \%$ (i.e., a multiplicative change in the odds ratio of 1.77). This finding indicates that, after controlling for age, education, 1.5 generation, and region, South Asian men have $77 \%$ higher odds of being employed in a higher occupational category.

Table 5 shows the estimates for the regression of log-wage for men in the 25 to 40 age range. The estimates are generally consistent with prior research (Sakamoto \& Furuichi, 1997). In this case, the exponent of the coefficient refers to the percentage change in wages for a unit change in the independent variable (Sakamoto \& Furuichi, 1997). For example, the results in Model 2 indicate that, relative to high school dropouts, a 
Table 1.

Descriptive statistics for men by age group.

\begin{tabular}{|c|c|c|c|c|c|c|c|c|}
\hline \multirow[b]{3}{*}{ Variable } & \multicolumn{4}{|c|}{ Aged 25 to 64} & \multicolumn{4}{|c|}{ Aged 25 to 40} \\
\hline & \multicolumn{2}{|c|}{ White } & \multicolumn{2}{|c|}{ South Asian } & \multicolumn{2}{|c|}{ White } & \multicolumn{2}{|c|}{ South Asian } \\
\hline & Proportion & & Proportion & & Proportion & & Proportion & \\
\hline Native-Born & 0.99 & & 0.49 & & 0.98 & & 0.45 & \\
\hline 1.5 Generation & 0.01 & & 0.51 & & 0.02 & & 0.55 & \\
\hline \multicolumn{9}{|l|}{ Education } \\
\hline Less than High School & 0.06 & & 0.03 & & 0.07 & & 0.03 & \\
\hline High School & 0.29 & & 0.08 & & 0.28 & & 0.08 & \\
\hline Some College & 0.22 & & 0.10 & & 0.22 & & 0.09 & \\
\hline Associate Degree & 0.08 & & 0.05 & & 0.09 & & 0.05 & \\
\hline Four Year College Degree & 0.23 & & 0.38 & & 0.24 & & 0.38 & \\
\hline More than College Degree & 0.12 & & 0.36 & & 0.09 & & 0.36 & \\
\hline \multicolumn{9}{|l|}{ Region } \\
\hline New England & 0.06 & & 0.05 & & 0.05 & & 0.05 & \\
\hline Middle Atlantic & 0.13 & & 0.28 & & 0.13 & & 0.29 & \\
\hline East North Central & 0.19 & & 0.13 & & 0.19 & & 0.13 & \\
\hline West North Central & 0.09 & & 0.02 & & 0.09 & & 0.02 & \\
\hline South Atlantic & 0.18 & & 0.16 & & 0.18 & & 0.16 & \\
\hline East South Central & 0.07 & & 0.02 & & 0.07 & & 0.02 & \\
\hline West South Central & 0.09 & & 0.09 & & 0.10 & & 0.09 & \\
\hline Mountain & 0.07 & & 0.03 & & 0.08 & & 0.03 & \\
\hline Pacific & 0.12 & & 0.22 & & 0.12 & & 0.22 & \\
\hline Aggregated Occupation Category $1^{\mathrm{a}}$ & 37.11 & & 67.85 & & 34.61 & & 68.49 & \\
\hline Aggregated Occupation Category $2^{\mathrm{b}}$ & 27.00 & & 23.98 & & 28.69 & & 24.21 & \\
\hline Aggregated Occupation Category $3^{c}$ & 35.31 & & 8.04 & & 36.06 & & 7.18 & \\
\hline \multirow[t]{2}{*}{ Aggregated Occupation Category $4^{\mathrm{d}}$} & 0.58 & & 0.13 & & 0.64 & & 0.11 & \\
\hline & Mean & SD & Mean & SD & Mean & SD & Mean & SD \\
\hline Age & 43.44 & 60.66 & 32.49 & 38.07 & 32.56 & 28.11 & 31.44 & 27.91 \\
\hline Age-Squared & 2002.54 & 5312.36 & 1092.10 & 2819.11 & 1082.53 & 1830.26 & 1008.10 & 1793.54 \\
\hline Wage & 28.46 & 165.57 & 34.11 & 220.27 & 23.57 & 136.84 & 33.81 & 213.79 \\
\hline Log-Wage & 3.06 & 4.10 & 3.20 & 5.04 & 2.92 & 4.01 & 3.20 & 4.99 \\
\hline Sample Size & $1,284,972$ & & 2400 & & 472,550 & & 2240 & \\
\hline
\end{tabular}

Notes: a Category 1 includes management, business, finance, computer, engineering, science, education, legal, community service, arts, media, healthcare and technical occupations; ${ }^{b}$ Category 2 includes service, sales, office and administrative support occupations; 'Category 3 includes construction, extraction, installation, maintenance, repair, production, transportation and material moving occupations; ${ }^{\mathrm{d} C a t e g o r y ~} 4$ includes farming, fishing and forestry occupations.

worker with a bachelor's degree has a wage that is $83 \%$ higher (i.e., $\exp (0.604)=1.83$ or an $83 \%$ multiplicative change in the wage) after controlling for the effects of age, 1.5 generation, region, and race.

As was the case with occupational attainment in Table 3, the findings in Table 5 indicate that South Asian men are advantaged in the labor market in regard to wages. The results for Model 1 in Table 5 show that, without controlling for region, the net advantage of being South Asian is 7.8\%. In Model 2, the net advantage declines slightly to $5.8 \%$ after controlling for region. Both of these results are highly significant indicating that these estimated net wage advantages for South Asian men are very unlikely to be the results of random sampling error.

\section{Statistical Findings for Women}

Table 2 shows the descriptive statistics for white and South Asian women. They are broken down for the age range from 25 to 64 and from 25 to 40 . The younger age distribution for South Asian women relative to white women is just as evident in Ta- 
Table 2.

Descriptive statistics for women by age group.

\begin{tabular}{|c|c|c|c|c|c|c|c|c|}
\hline & \multicolumn{4}{|c|}{ Aged 25 to 64} & \multicolumn{4}{|c|}{ Aged 25 to 40} \\
\hline & \multicolumn{2}{|c|}{ White } & \multicolumn{2}{|c|}{ South Asian } & \multicolumn{2}{|c|}{ White } & \multicolumn{2}{|c|}{ South Asian } \\
\hline Variable & Proportion & & Proportion & & Proportion & & Proportion & \\
\hline Native-Born & 0.99 & & 0.49 & & 0.98 & & 0.46 & \\
\hline 1.5 Generation & 0.01 & & 0.51 & & 0.02 & & 0.54 & \\
\hline \multicolumn{9}{|l|}{ Education } \\
\hline Less than High School & 0.04 & & 0.02 & & 0.04 & & 0.02 & \\
\hline High School & 0.26 & & 0.07 & & 0.21 & & 0.06 & \\
\hline Some College & 0.23 & & 0.09 & & 0.23 & & 0.09 & \\
\hline Associate Degree & 0.11 & & 0.05 & & 0.11 & & 0.05 & \\
\hline Four Year College Degree & 0.23 & & 0.40 & & 0.28 & & 0.40 & \\
\hline More than College Degree & 0.13 & & 0.37 & & 0.13 & & 0.38 & \\
\hline \multicolumn{9}{|l|}{ Region } \\
\hline New England & 0.06 & & 0.04 & & 0.06 & & 0.04 & \\
\hline Middle Atlantic & 0.14 & & 0.26 & & 0.13 & & 0.26 & \\
\hline East North Central & 0.19 & & 0.15 & & 0.19 & & 0.16 & \\
\hline West North Central & 0.09 & & 0.02 & & 0.09 & & 0.02 & \\
\hline South Atlantic & 0.18 & & 0.19 & & 0.18 & & 0.19 & \\
\hline East South Central & 0.06 & & 0.02 & & 0.07 & & 0.02 & \\
\hline West South Central & 0.09 & & 0.09 & & 0.10 & & 0.08 & \\
\hline Mountain & 0.07 & & 0.03 & & 0.01 & & 0.03 & \\
\hline Pacific & 0.11 & & 0.21 & & 0.11 & & 0.21 & \\
\hline Aggregated Occupation Category $1^{\mathrm{a}}$ & 45.14 & & 70.64 & & 46.20 & & 71.12 & \\
\hline Aggregated Occupation Category $2^{\mathrm{b}}$ & 48.57 & & 27.24 & & 48.21 & & 26.75 & \\
\hline Aggregated Occupation Category $3^{c}$ & 6.11 & & 2.03 & & 5.42 & & 2.03 & \\
\hline \multirow[t]{2}{*}{ Aggregated Occupation Category $4^{\mathrm{d}}$} & 0.18 & & 0.09 & & 0.17 & & 0.09 & \\
\hline & Mean & SD & Mean & SD & Mean & SD & Mean & SD \\
\hline Age & 43.69 & 59.82 & 32.17 & 36.87 & 32.47 & 27.80 & 31.10 & 26.23 \\
\hline Age-Squared & 2024.91 & 5237.78 & 1072.73 & 2758.89 & 1077.07 & 1808.35 & 986.22 & 1677.05 \\
\hline Wage & 21.16 & 119.78 & 30.28 & 193.59 & 19.55 & 113.30 & 30.63 & 197.35 \\
\hline Log-Wage & 2.79 & 3.88 & 3.11 & 4.56 & 2.73 & 4.01 & 3.12 & 4.57 \\
\hline Sample Size & 1,213,192 & & 2105 & & 434,248 & & 1964 & \\
\hline
\end{tabular}

Notes: a Category 1 includes management, business, finance, computer, engineering, science, education, legal, community service, arts, media, healthcare and technical occupations; ${ }^{b}$ Category 2 includes service, sales, office and administrative support occupations; 'Category 3 includes construction, extraction, installation, maintenance, repair, production, transportation and material moving occupations; ${ }^{\mathrm{d} C a t e g o r y ~} 4$ includes farming, fishing and forestry occupations.

ble 2 as it was for South Asian men relative to white men in Table 1. We will therefore, for the same reasons, focus on the 25 to 40 age range in our discussion.

For that age range, the results in Table 2 show that the educational advantage of South Asian women over white women is even slightly greater than the educational advantage of South Asian men over white men (which is shown in Table 1). Relative to white women, South Asian women are also more likely to reside in the Middle Atlantic or Pacific regions, and to be employed in the highest occupational category. South Asian women are more likely to be 1.5 generation as was the case for South Asian men.

Table 4 shows the estimates for the ordered logistic regression of occupational attainment for women in the 25 to 40 age range. The estimates are again contrary to the expectations of the MMM view and white privilege theory. Model 2 in Table 4 shows that the occupational advantage of South Asian women over white women is $24 \%$ after controlling for age, education, 1.5 generation, and region. The net racial advantage in occupational attainment for South Asian women is thus for smaller 
Table 3.

Estimates of ordered logit models for men aged 25 to 40 .

\begin{tabular}{|c|c|c|c|c|c|c|c|c|}
\hline \multirow[b]{2}{*}{ Variable } & \multicolumn{4}{|c|}{ Model 1} & \multicolumn{4}{|c|}{ Model 2} \\
\hline & Estimate & & Odds Ratio & SE & Estimate & & Odds Ratio & SE \\
\hline Intercept 1 & -3.198 & $* * *$ & & 0.027 & -3.085 & *** & & 0.027 \\
\hline Intercept 2 & -1.560 & *** & & 0.027 & -1.442 & $* * *$ & & 0.027 \\
\hline Intercept 3 & 3.309 & $* * *$ & & 0.027 & 3.439 & $* * *$ & & 0.027 \\
\hline 1.5 Generation (Native-Born) & 0.248 & $* * *$ & 1.282 & 0.004 & 0.209 & $* * *$ & 1.233 & 0.004 \\
\hline South Asian (Non-Hispanic White) & 0.594 & $* * *$ & 1.810 & 0.008 & 0.572 & *** & 1.772 & 0.008 \\
\hline Age & 0.031 & *** & 1.032 & 0.002 & 0.035 & *** & 1.036 & 0.002 \\
\hline Age-Squared & 0.000 & ${ }^{* * *}$ & 1.000 & 0.000 & 0.000 & $* * *$ & 1.000 & 0.000 \\
\hline \multicolumn{9}{|l|}{ Education (Less than High School) } \\
\hline High School & 0.434 & $* * *$ & 1.543 & 0.002 & 0.437 & $* * *$ & 1.547 & 0.002 \\
\hline Some College & 1.343 & $* * *$ & 3.832 & 0.002 & 1.339 & $* * *$ & 3.816 & 0.002 \\
\hline Associate Degree & 1.683 & *** & 5.381 & 0.003 & 1.683 & *** & 5.381 & 0.003 \\
\hline Four Year College Degree & 3.019 & $* * *$ & 20.463 & 0.002 & 3.014 & $* * *$ & 20.377 & 0.002 \\
\hline More than College Degree & 4.356 & $* * *$ & 77.954 & 0.003 & 4.352 & $* * *$ & 77.606 & 0.003 \\
\hline \multicolumn{9}{|l|}{ Region (Pacific) } \\
\hline New England & & & & & -0.097 & $* * *$ & 0.907 & 0.003 \\
\hline Middle Atlantic & & & & & -0.150 & ${ }^{* * *}$ & 0.861 & 0.002 \\
\hline East North Central & & & & & -0.343 & $* * *$ & 0.710 & 0.002 \\
\hline West North Central & & & & & -0.350 & $* * *$ & 0.705 & 0.002 \\
\hline South Atlantic & & & & & -0.076 & ${ }^{* * *}$ & 0.927 & 0.002 \\
\hline East South Central & & & & & -0.350 & $* * *$ & 0.705 & 0.002 \\
\hline West South Central & & & & & -0.120 & ${ }^{* * *}$ & 0.887 & 0.002 \\
\hline Mountain & & & & & -0.066 & $* * *$ & 0.936 & 0.002 \\
\hline$-2 L L$ & $31,507,756$ & & & & $31,436,249$ & & & \\
\hline
\end{tabular}

${ }^{* * *} \mathrm{p}<0.001$. Source: 2006-2008 American Community Survey $(\mathrm{N}=474,790)$. Note: Values in parentheses are reference categories.

than the net racial advantage in occupational attainment for South Asian men as is shown in Table 3.

Table 6 shows the estimates of the log-wage regression for women. In Model 1 without controlling for region, the net advantage for South Asian women is $17.0 \%$ while in Model 2, the net advantage declines slightly to $15.0 \%$ after controlling for region. Both of these results are highly significant. The net racial advantage in wages for South Asian women as shown in Table 6 is evidently larger than the net racial advantage in wages for South Asian men as shown in Table 5. Thus, the net racial advantage in occupational attainment for South Asian women (i.e., Table 4) is smaller than the net racial advantage in occupational attainment for South Asian men (i.e., Table 3) but the net racial advantage in wages for South Asian women (i.e., Table 6) is larger than the net racial advantage in wages for South Asian men (i.e., Table 5).

\section{Discussions and Conclusion}

According to Collins (1989), social theory differs from ideology in several ways, but perhaps the most critical difference is that social theory seeks to amend its explanations of social phenomena by comparing empirical data to the predictions derived from it. That is, social theory differs from ideology in that the latter is much less concerned with systematically testing whether its expectations about the empirical world are actually in fact ever observed. Social theory should therefore constantly strive to be relevant by providing valid explanations of the real world in the sense that its analytical predictions are compared with the observed facts and then amended in order to seek to coincide with them as much as possible.

In the foregoing, we have investigated the socioeconomic attainments of second generation South Asian men using the most recent data. The empirical results show that this group has higher education, occupational attainment, and wages than white men. Indeed, even after controlling for age, education, 1.5 generation, and region, South Asian men still remain slightly advantaged over white men in terms of having 5.8\% higher wages and $77 \%$ higher odds for occupational attainment. Similar results are evident for South Asian women although their net advantage over white women is $15 \%$ higher wages and $24 \%$ higher odds for occupational attainment. 
Table 4.

Estimates of ordered logit models for women aged 25 to 40.

\begin{tabular}{|c|c|c|c|c|c|c|c|c|}
\hline \multirow[b]{2}{*}{ Variable } & \multicolumn{4}{|c|}{ Model 1} & \multicolumn{4}{|c|}{ Model 2} \\
\hline & Estimate & & Odds Ratio & SE & Estimate & & Odds Ratio & SE \\
\hline Intercept 1 & -4.518 & $* * *$ & & 0.031 & -4.487 & ${ }^{* * *}$ & & 0.031 \\
\hline Intercept 2 & -0.922 & $* * *$ & & 0.031 & -0.883 & ${ }^{* * *}$ & & 0.031 \\
\hline Intercept 3 & 2.657 & *** & & 0.031 & 2.699 & $* * *$ & & 0.032 \\
\hline 1.5 Generation (Native-Born) & 0.071 & $* * *$ & 1.073 & 0.004 & 0.052 & $* * *$ & 1.054 & 0.004 \\
\hline South Asian (Non-Hispanic White) & 0.220 & *** & 1.246 & 0.010 & 0.217 & $* * *$ & 1.243 & 0.010 \\
\hline Age & 0.135 & *** & 1.145 & 0.002 & 0.135 & ${ }^{* * *}$ & 1.145 & 0.002 \\
\hline Age-Squared & -0.002 & $* * *$ & 0.998 & 0.000 & -0.002 & ${ }^{* * *}$ & 0.998 & 0.000 \\
\hline \multicolumn{9}{|l|}{ Education (Less than High School) } \\
\hline High School & 0.518 & *** & 1.678 & 0.003 & 0.527 & ${ }^{* * *}$ & 1.693 & 0.003 \\
\hline Some College & 1.171 & *** & 3.224 & 0.003 & 1.178 & $* * *$ & 3.247 & 0.003 \\
\hline Associate Degree & 2.079 & *** & 7.996 & 0.003 & 2.097 & *** & 8.145 & 0.003 \\
\hline Four Year College Degree & 2.887 & $* * *$ & 17.932 & 0.003 & 2.898 & $* * *$ & 18.130 & 0.003 \\
\hline More than College Degree & 4.293 & $* * *$ & 73.176 & 0.004 & 4.308 & $* * *$ & 74.321 & 0.004 \\
\hline \multicolumn{9}{|l|}{ Region (Pacific) } \\
\hline New England & & & & & -0.018 & $* * *$ & 0.982 & 0.003 \\
\hline Middle Atlantic & & & & & -0.054 & ${ }^{* * *}$ & 0.948 & 0.002 \\
\hline East North Central & & & & & -0.200 & ${ }^{* * *}$ & 0.818 & 0.002 \\
\hline West North Central & & & & & -0.112 & $* * *$ & 0.894 & 0.003 \\
\hline South Atlantic & & & & & 0.055 & $* * *$ & 1.056 & 0.002 \\
\hline East South Central & & & & & -0.096 & $* * *$ & 0.909 & 0.003 \\
\hline West South Central & & & & & 0.163 & $* * *$ & 1.177 & 0.003 \\
\hline Mountain & & & & & -0.036 & ${ }^{* * *}$ & 0.965 & 0.003 \\
\hline$-2 \mathrm{LL}$ & $21,410,633$ & & & & $21,375,590$ & & & \\
\hline
\end{tabular}

${ }^{* * *} \mathrm{p}<0.001$. Source: 2006-2008 American Community Survey $(\mathrm{N}=436,212)$. Note: Values in parentheses are reference categories.

In terms of quantitative research, prior studies have almost entirely ignored second generation South Asians. Similarly, discussions of white privilege and the MMM view have not explicitly noted the existence of second generation South Asians. The results of our foregoing empirical analysis suggest, however, that this demographic group defies the predictions of both white privilege theory and the MMM view. That is, the advantaged socioeconomic attainments of second generation South Asians are exactly the reverse of what is predicted by white privilege theory and the MMM view. By ignoring South Asians, the proponents of these theories have conveniently avoided having to confront such "inconvenient facts" (Weber, 1946: p. 147 [1922]).

In any event, our findings do not appear to support the generalization that second generation South Asians currently encounter a systematic socioeconomic disadvantage due to being a minority group with darker skin tones (at least on average). Our findings are thus not consistent with the application of strong claims about a rigid "pigmentocracy" (Bonilla-Silva, 2003: p. 121) to second generation South Asians. Nor do we find any evidence that, as predicted by the MMM view, second generation South Asians must make a higher investment in human capital in order to obtain the same labor market rewards as whites. To the contrary, the reverse seems more likely to be true as second generation South Asians are actually advantaged over whites in regard to wages and occupational attainment. Given the high levels of inequality that characterize these latter two variables in the 21st century (Lemieux, 2006), this advantage is not trivial.

We speculate that these results may in part reflect the increasing significance of educational attainment for labor market success in the 21st century. Kim and Sakamoto (2008) report a $47 \%$ relative increase in the explanatory power of basic educational levels in predicting wage inequality in recent decades while the explanatory power of three-digit occupations declined. Other studies indicate increases in the economic returns to college attainment (Card \& DiNardo, 2002; Becker \& Murphy, 2007) while Lemieux (2006) argues that notably high wages are increasingly associated with postsecondary education. The fact that second generation South Asians have higher levels of educational attainment than whites suggests the labor market advantage of the former demographic group may increasingly 
Table 5.

Estimates of OLS regression of log-wage for men aged 25 to 40.

\begin{tabular}{|c|c|c|c|c|}
\hline \multirow[b]{2}{*}{ Variable } & \multicolumn{2}{|c|}{ Model 1} & \multicolumn{2}{|c|}{ Model 2} \\
\hline & Estimate & SE & Estimate & SE \\
\hline Intercept & 0.278 & **** 0.048 & 0.357 & ${ }^{* * * *} 0.048$ \\
\hline 1.5 Generation (Native-Born) & 0.046 & ${ }^{* * *} 0.006$ & 0.027 & ${ }^{* * *} 0.006$ \\
\hline South Asian (Non-Hispanic White) & 0.075 & **** 0.013 & 0.056 & ${ }^{* * *} 0.013$ \\
\hline Age & 0.109 & ${ }^{* * *} 0.003$ & 0.111 & ${ }^{* * *} 0.003$ \\
\hline Age-Squared & -0.001 & ${ }^{* * *} 0.000$ & -0.001 & ${ }^{* * *} 0.000$ \\
\hline \multicolumn{5}{|l|}{ Education (Less than High School) } \\
\hline High School & 0.165 & ${ }^{* * *} 0.004$ & 0.158 & ${ }^{* * *} 0.004$ \\
\hline Some College & 0.291 & **** 0.004 & 0.282 & ${ }^{* * *} 0.004$ \\
\hline Associate Degree & 0.365 & **** 0.005 & 0.355 & ${ }^{* * *} 0.005$ \\
\hline Four Year College Degree & 0.620 & ${ }^{* * *} 0.004$ & 0.604 & ${ }^{* * *} 0.004$ \\
\hline More than College Degree & 0.806 & **** 0.004 & 0.788 & ${ }^{* * *} 0.004$ \\
\hline \multicolumn{5}{|l|}{ Region (Pacific) } \\
\hline New England & & & -0.025 & ${ }^{* * *} 0.005$ \\
\hline Middle Atlantic & & & -0.033 & ${ }^{* * *} 0.004$ \\
\hline East North Central & & & -0.116 & ${ }^{* * *} 0.003$ \\
\hline West North Central & & & -0.168 & ${ }^{* * * *} 0.004$ \\
\hline South Atlantic & & & -0.114 & ${ }^{* * *} 0.003$ \\
\hline East South Central & & & -0.205 & ${ }^{* * *} 0.004$ \\
\hline West South Central & & & -0.138 & ${ }^{* * *} 0.004$ \\
\hline Mountain & & & -0.114 & ${ }^{* * *} 0.004$ \\
\hline R-Squared & 0.187 & & 0.195 & \\
\hline
\end{tabular}

${ }^{* * *} \mathrm{p}<0.001$. Source: 2006-2008 American Community Survey $(\mathrm{N}=474,790)$. Note: Values in parentheses are reference categories.

become secure as high educational attainment (i.e., a college degree) is becoming a necessary prerequisite for mobility out of the low-wage labor market (Card \& DiNardo, 2006).

Some additional evidence suggests that second generation Asian American men (including South Asians) are more highly concentrated in science, technology, engineering and medical (i.e., STEM) fields of study that tend to have higher earnings (Kim \& Sakamoto, 2010). Although the results are still preliminary, such a pattern might be a potential explanation for the advantage of South Asians over whites. Because STEM fields of study tend to have higher labor market returns, the higher wages and occupational attainment of South Asians would be expected given their higher concentration in STEM areas. The higher racial wage advantage for South Asian women in relation to South Asian men may reflect the lower gender differential in STEM concentration among South Asians than among whites. The lower racial occupational advantage for South Asian women in relation to South Asian men may reflect the measurement limitations of our occupational typology if white women are more highly concentrated in administrative white collar positions (e.g., secretaries) that are ranked relatively highly in our occupational classification. This issue is certainly an appropriate area for future research.
Table 6.

Estimates of OLS regression of log-wage for women aged 25 to 40.

\begin{tabular}{|c|c|c|c|c|}
\hline & \multicolumn{2}{|c|}{ Model 1} & \multicolumn{2}{|c|}{ Model 2} \\
\hline Variable & Estimate & SE & Estimate & SE \\
\hline Intercept & 0.308 & ${ }^{* * *} 0.051$ & 0.396 & ${ }^{* * *} 0.051$ \\
\hline 1.5 Generation (Native-Born) & 0.082 & **** 0.007 & 0.061 & ${ }^{* * *} 0.007$ \\
\hline South Asian (Non-Hispanic White) & 0.157 & *** 0.014 & 0.140 & ${ }^{* * *} 0.014$ \\
\hline Age & 0.098 & ${ }^{* * *} 0.003$ & 0.100 & ${ }^{* * *} 0.003$ \\
\hline Age-Squared & -0.001 & **** 0.000 & -0.001 & **** 0.000 \\
\hline \multicolumn{5}{|l|}{ Education (Less than High School) } \\
\hline High School & 0.210 & ${ }^{* * *} 0.005$ & 0.203 & ${ }^{* * *} 0.005$ \\
\hline Some College & 0.348 & ${ }^{* * *} 0.005$ & 0.341 & ${ }^{* * *} 0.005$ \\
\hline Associate Degree & 0.524 & *** 0.005 & 0.515 & ${ }^{* * *} 0.005$ \\
\hline Four Year College Degree & 0.759 & ${ }^{* * *} 0.005$ & 0.744 & ${ }^{* * *} 0.005$ \\
\hline More than College Degree & 0.967 & ${ }^{* * *} 0.005$ & 0.944 & ${ }^{* * * *} 0.005$ \\
\hline \multicolumn{5}{|l|}{ Region (Pacific) } \\
\hline New England & & & -0.022 & ${ }^{* * *} 0.005$ \\
\hline Middle Atlantic & & & -0.040 & **** 0.004 \\
\hline East North Central & & & -0.138 & **** 0.003 \\
\hline West North Central & & & -0.196 & ${ }^{* * *} 0.004$ \\
\hline South Atlantic & & & -0.108 & ${ }^{* * * *} 0.004$ \\
\hline East South Central & & & -0.231 & ${ }^{* * *} 0.004$ \\
\hline West South Central & & & -0.161 & ${ }^{* * *} 0.004$ \\
\hline Mountain & & & -0.130 & *** 0.004 \\
\hline R-Squared & 0.194 & & 0.204 & \\
\hline
\end{tabular}

${ }^{* * *} \mathrm{p}<0.001$. Source: 2006-2008 American Community Survey $(\mathrm{N}=436,212)$. Note: Values in parentheses are reference categories.

One control variable that is not explicitly included in our regression models is being second generation itself which relates to the issue of "immigrant optimism" (Kao \& Tienda, 1995). This idea suggests that the second generation may have high socioeconomic attainments due to greater selectivity, effort, ambition and motivation. Second generation children are frequently reminded of the sacrifices that their parents have made in order to come to America often for the purpose of obtaining better socioeconomic opportunities. Immigrant parents who lack US educational credentials may find that their own labor market prospects are constrained, and may alternatively motivate their children into becoming high achievers (Goyette \& Xie, 1999; Sakamoto, Goyette, \& Kim, 2009).

This process of "immigrant optimism" may help to explain the slight net advantage of being 1.5 generation that was evident in all of our regression models. The 1.5 generation may be more likely to have more highly motivated immigrant parents who have yet to have fully achieved the higher standard of living that is more typical of American society. If so, such more recent immigrant parents may more greatly influence their children into becoming economically successful. ${ }^{3}$

\footnotetext{
${ }^{3}$ Note that the 1.5 generation effect and "immigrant optimism" are not restricted to Asian Americans. Thus, the estimated effects of 1.5 generation shown in the tables for the regression results apply equally to both whites and South Asians.
} 
An additional theme in this general literature is the selective retention of traditional values and customs (sometimes known as "segmented assimilation") that might serve as resources for upward mobility or improved socioeconomic attainments in the more multicultural environment of contemporary America. As stated by (Zhou, 1997: p. 994), “Asian subgroups selectively unpack from their cultural baggage those traits suitable to the new environment, such as two parent families, a strong work ethic, delayed gratification, and thrift...”. Zhou (1997: p. 988) also notes that by maintaining some traditional values and norms, Asian American children may be better equipped to counteract the "oppositional culture" and "poverty, poor schools, violence, drugs, and a generally disruptive social environment" in the inner city. The "segmented assimilation" perspective thus suggests that limited or incomplete integration into American society may actually improve the socioeconomic attainments of Asian Americans.

Xie and Goyette (2004: p. 10) report, for example, that 53\% of recent cohorts of native born Asian Americans complete college as compared to $30 \%$ among whites. This Asian American advantage in education may be in part facilitated by traditional Asian values and norms regarding family cohesiveness, the parental control of children, and children's sense of filial piety towards accommodating their parents' wishes (Goyette \& Xie, 1999; Sakamoto, Goyette, \& Kim, 2009). While the selectivity of Asian immigration towards persons who are more highly educated plays an important role as well, every known study on this issue finds that social class factors alone cannot fully account for the higher educational attainments of Asian American youth over white youth (Sakamoto, Goyette, \& Kim, 2009). Thus, "segmented assimilation” processes including "immigrant optimism" may be conducive towards high educational attainment among second generation Asian American youth including South Asians.

In sum, our findings of higher socioeconomic attainments among South Asians may perhaps be explained as deriving from the selectivity of being second generation when combined with Asian American family patterns that emphasize educational attainment and upward social mobility. If this interpretation is approximately accurate, then it would seem to be consistent with Wilson's (2009) more general view that ethnic subcultures may sometimes interact with class positions to affect the socioeconomic attainments of children. More research on this complex issue is obviously clearly warranted.

\section{REFERENCES}

Becker, G. S., \& Murphy, K. M. (2007). Education and consumption: The effects of education in the household compared to the marketplace. Journal of Human Capital, 1, 9-35. doi:10.1086/524715

Bonilla-Silva, E. (1997). Rethinking racism: Toward a structural interpretation. American Sociological Review, 62, 465-480. doi:10.2307/2657316

Bonilla-Silva, E. (2001). White supremacy and racism in the post-civil rights era. Boulder, CO: Lynne Rienner.

Bonilla-Silva, E. (2003). Racism without racists. Lanham, MD: Rowman and Littlefield.

Bonilla-Silva, E., \& Glover, K. (2004). We are all Americans: The Latin Americanization of race relations in the USA. In M. Krysan, \& A. E. Lewis (Eds.), The changing terrain of race and ethnicity (pp. 149-186). New York: Russell Sage Foundation.

Bratsberg, B., \& Ragan, J. F. Jr. (2002). The impact of host-country schooling on earnings: A study of male immigrants in the United States. Journal of Human Resources, 37, 63-105. doi: $10.2307 / 3069604$

Card, D., \& DiNardo, J. E. (2002). Skill biased technological change and rising wage inequality: Some problems and puzzles. Journal of Labor Economics, 20, 733-783. doi:10.1086/342055

Card, D., \& DiNardo, J. E. (2006). Work and poverty during the past quarter-century. In R. M. Blank, S. H. Danziger, \& R. F. Schoeni (Eds.), Working and poor: How economic and policy changes are affecting low-wage workers (pp. 1-20). New York: Russell Sage Foundation.

Collins, R. (1989). Sociology: Pro-science or anti-science? American Sociological Review, 53, 124-139. doi:10.2307/2095666

Dingra, P. (2003). Being American between Black and White: Second generation Asian American professionals' racial identities. Journal of Asian American Studies, 6, 117-147.

Duleep, H. O., \& Regets, M. C. (1997). Measuring immigrant wage growth using matched CPS files. Demography, 34, 239-249. doi: $10.2307 / 2061702$

Duleep, H. O., \& Sanders, S. (1992). Discrimination at the top: American-born Asian and White men. Industrial Relations, 31, 416-432. doi:10.1111/j.1468-232X.1992.tb00318.x

Farley, R., \& Alba, R. (2002). The new second generation in the United States. International Migration Review, 36, 669-701. doi:10.1111/j.1747-7379.2002.tb00100.x

Feagin, J. R. (2001). Racist America. London: Routledge.

Feagin, J. R., \& Vera, H. (2005). White racism: The basics. London: Routledge.

Goyette, K. A., \& Xie, Y. (1999). Educational expectations of Asian American youths: Determinants and ethnic differences. Sociology of Education, 72, 22-36. doi:10.2307/2673184

Hirschman, C., \& Snipp, C. M. (2001). The state of the American dream: Race and ethnic socioeconomic inequality in the United States, 1970-1990. In D. B. Grusky (Ed.), Social stratification (pp. 623-642). Boulder: Westview.

Hirschman, C., \& Wong, M. G. (1984). Socioeconomic gains of Asian Americans, Blacks, and Hispanics: 1960-1976. American Journal of Sociology, 90, 584-607. doi:10.1086/228118

Hurh, W. M., \& Kim, K. C. (1989). The "success" image of Asian Americans: Its validity, and its practical and theoretical implications. Ethnic and Racial Studies, 12, 512-536. doi:10.1080/01419870.1989.9993650

Jensen, J. M. (1988). Passage from India. New Haven, CT: Yale University Press.

Kao, G., \& Tienda, M. (1995). Optimism and achievement: The educational performance of immigrant youth. Social Science Quarterly, 76, $1-19$.

Kibria, N. (2006). South Asian Americans. In P. G. Min (Ed.), Asian Americans: Contemporary trends and issues (pp. 206-227). Thousand Oaks: Sage Publications.

Kim, C., \& Sakamoto, A. (2008). The rise of intra-occupational wage inequality in the United States, 1983 to 2002. American Sociological Review, 73, 129-157. doi:10.1177/000312240807300107

Kim, C., \& Sakamoto, A. (2010). Has a racial minority obtained labor market parity with Whites? Demographic heterogeneity, over-education, and the earnings of Asian American men. (unpublished manuscript)

Kitano, H. L., \& Daniels, R. (2000). Asian Americans: Emerging minorities. Upper Saddle River, NJ: Prentice Hall.

Lemieux, T. (2006). Postsecondary education and increasing wage inequality. American Economic Review, 96, 195-199. doi:10.1257/000282806777211667

McCall, L. (2001). Sources of racial wage inequality in metropolitan labor markets: Racial, ethnic, and gender differences. American Sociological Review, 66, 520-541. doi:10.2307/3088921

Min, P. G. (1995). Asian Americans: Contemporary trends and issues. Thousand Oaks, CA: Sage Publications.

Min, P. G. (2006). Asian immigration: History and contemporary trends. In P. G. Min (Ed.), Asian Americans: Contemporary trends and issues (pp. 7-31). Thousand Oaks: Sage Publications.

Omi, M., \& Winant, H. (1994). Racial formation in the United States. 
London: Routledge.

Portes, A., \& Rumbaut, R. G. (2005). Introduction: The second generation and the children of immigrants longitudinal study. Ethnic and Racial Studies, 28, 983-999. doi:10.1080/01419870500224109

Portes, A., \& Zhou, M. (1995). Divergent destinies: Immigration, poverty and entrepreneurship in the United States. In K. McFate, R. Lawton, \& W. J. Wilson (Eds.), Poverty, inequality and the future of social policy (pp. 489-520). New York: Russell Sage Foundation.

Reeves, T. J., \& Bennett, C. E. (2004). We the people: Asians in the United States. Census 2000 Special Report, US Census Bureau. US Government Printing Office.

Saenz, R., \& Morales, M. C. (2005). Chapter 6: Demography of race and ethnicity. In D. L. Poston and M. Micklin (Eds.), Handbook of population (pp. 169-208). New York: Springer Publishers. doi:10.1007/0-387-23106-4_7

Sakamoto, A., \& Furuichi, S. (2002). The wages of native-born Asian Americans at the end of the twentieth century. Asian American Policy Review, 10, 17-30.

Sakamoto, A., \& Furuichi, S. (1997). Wages among White and Japanese-American male workers. Research in Social Stratification and Mobility, 15, 177-206.

Sakamoto, A., Goyette, K. A., \& Kim, C. (2009). Socioeconomic attainments of Asian Americans. Annual Review of Sociology, 35, 255-276. doi:10.1146/annurev-soc-070308-115958

Sanders, J. M., \& Nee, V. (1996). Immigrant self-employment: The family as social capital and the value of human capital. American Sociological Review, 61, 231-249. doi:10.2307/2096333

Matthew, S. C., \& Hirschman, C. (2005). Assimilation in American society: Occupational achievement and earnings for ethnic minorities in the United States, 1970 to 1990. Research in Social Stratification and Mobility, 522, 93-117.
Stokowski, R. P., Pant, P. V. K., Dadd, T., Fereday, A., Hinds, D. A., Jarman, C., Filsell, W., Ginger, R. S., Green, M. R., van der Ouderaa, F. J., \& Cox, D. R. (2007). A genomewide association study of skin pigmentation in a south Asian population. American Journal of $\mathrm{Hu}-$ man Genetics, 81, 1119-1132. doi:10.1086/522235

Takaki, R. (1998). Strangers from a different shore. New York: Little, Brown and Company.

Waters, M. C., \& Eschbach, K. (1995). Immigration and ethnic and racial inequality in the United States. Annual Review of Sociology, 21, 419-446. doi:10.1146/annurev.so.21.080195.002223

Weber, M. (1946 [1922]). Science as a Vocation. In H. H. Gerth, \& C. W. Mills (Eds.), From Max Weber: Essays in sociology (pp. 129-156). Oxford: Oxford University Press.

Wilson, W. J. (2009). More than just race: Being black and poor in the inner city. New York: W.W. Norton \& Company.

Xie, Y., \& Goyette, K. A. (2004). Asian Americans: A demographic portrait. New York: Russell Sage Foundation.

Zeng, Z., \& Xie, Y. (2004). Asian Americans' earnings disadvantage reexamined: The role of place of education. American Journal of Sociology, 109, 1075-1108. doi:10.1086/381914

Zhou, M. (1997). Segmented assimilation: Issues, controversies, and recent research on the new second generation. International Migration Review, 31, 975-1008. doi:10.2307/2547421

Zhou, M. (2004). Coming of age at the turn of the twenty-first century: A demographic profile of Asian American youth. In J. Lee, \& M. Zhou (Eds.), Asian American youth (pp. 33-50). London: Routledge.

Zhou, M., \& Kamo, Y. (1994). An analysis of earnings patterns for Chinese, Japanese, and non-Hispanic White males in the United States. Sociological Quarterly, 35, 581-602. doi:10.1111/j.1533-8525.1994.tb00418.x 